\title{
STOCK PRICE REACTIONS TO CAPITAL STRUCTURE CHANGES IN CHILEAN FIRMS: EXAMINING THE EFFECTS OF OWNERSHIP STRUCTURE, GROWTH OPPORTUNITIES AND LEVERAGE
}

Reacción del precio de las acciones a los cambios de estructura de capital en empresas chilenas: Examinando los efectos de la estructura de propiedad, oportunidades de crecimiento y leverage

Jorge A. Muñoz Mendoza, Sandra M. Sepúlveda Yelpo, Carmen L. Veloso Ramos 


\title{
STOCK PRICE REACTIONS TO CAPITAL STRUCTURE CHANGES
}

\author{
in ChILEAN firms: Examining THE EFFECTS OF OWNERShIP
}

STRUCTURE, GROWTH OPPORTUNITIES AND LEVERAGE

\section{Reacción del precio de las acciones a los cambios \\ de estructura de capital en empresas chilenas: \\ Examinando los efectos de la estructura de propiedad, oportunidades de crecimiento y leverage*}

Jorge A. Muñoz Mendozaa, Sandra M. Sepúlveda Yelpo ${ }^{\text {, }}$ Carmen L. Veloso Ramos ${ }^{c}$

Palabras clave: Retornos anormales, Deuda, Estructura de capital, Expropiación de riqueza.

Keywords: Abnormal returns, Debt, Capital structure, Wealth expropriation.

IEL Classification: G14, G31, G32, G34

Received: $18 / 07 / 2018$

Accepted: 30/04/2020

Published: 28/05/2020

a. Profesor Asistente, departamento de Gestión Empresarial, Universidad de Concepción, Chile. Grupo de Investigación en Economía y Negocios (GEN) Universidad de Concepción.

E-Mail: jormunozm@udec.cl

ORCiD: https://orcid.org/0000-0002-6775-5307.

b. Profesor Asistente, departamento de Gestión Empresarial, Universidad de Concepción, Chile.

Grupo de Investigación en Economía y Negocios (GEN) Universidad de Concepción.

E-Mail: ssepulveday@udec.cl

ORCiD: https://orcid.org/0000-0002-2614-7356.

c. Profesor, departamento de Gestión

Empresarial, Universidad de Concepción, Chile. Grupo de Investigación en Economía y Negocios (GEN) Universidad de Concepción.

E-Mail: carmenveloso@udec.cl

ORCiD: https://orcid.org/0000-0001-9390-9974.

\section{Abstract}

We analyzed the effects of ownership structure, capital structure and growth opportunities on stock price reactions when companies issued debt or equity. Our results, based on event study methodology and IV regressions from a sample of 70 Chilean firms, indicate that controlling shareholder ownership has a negative effect on stock price reactions for debt issuances and a positive effect for equity issuance. These results indicate that debt issuances are a substitute for majority shareholder monitoring, and that equity issuances are associated with superior corporate performance. Equity issuances are a means for expropriating wealth from non-controlling shareholders. Debt and growth opportunities have a non-linear effect.

\section{Resumen}

En este artículo analizamos los efectos de la estructura de propiedad, estructura de capital y las oportunidades de crecimiento sobre la reacción del precio de las acciones cuando las empresas emiten deuda o capital. Nuestros resultados, basados en la metodología de análisis de eventos y regresiones IV sobre una muestra de 70 empresas chilenas, indican que la propiedad de los accionistas controladores tiene un efecto negativo en la reacción del precio de las acciones cuando las empresas emiten deuda y positivo cuando emiten acciones. Este 
resultado indica que las emisiones de deuda son un sustituto del control mayoritario de los accionistas y las emisiones de capital se asocian con un mayor desempeño corporativo. Las emisiones de capital son un medio para expropiar riqueza de los accionistas no controladores. Las oportunidades de deuda y crecimiento tienen un efecto no lineal.

\section{Introduction}

Capital structure decisions have been widely researched in recent decades. Many researchers have focused their attention on the relationship between information asymmetry and stock price reactions to changes in firms' capital structure, due to the possible effects of this relationship on shareholder wealth. In general, stock price reactions are associated with abnormal negative returns during security issuance periods, and positive returns during preceding periods (Asquith and Mullins, 1986; Mikkelson and Partch, 1986; Mitto, 1996; Welch, 2004; Vithessonthi, 2008a).

According to Masulis (1980), it is possible for controlling shareholders to expropriate wealth from minority shareholders through capital structure changes. This would depend on the firm's ownership structure, and especially on the participation of controlling and minority shareholders (Armitage, 2002. 2010; Liu et al., 2016). For the Chilean market, it is relevant to analyze this empirical relationship as Chile has weak investor protections, while firm ownership is highly concentrated among controlling shareholders. As a result, this favors wealth redistribution away from minority shareholders through capital structure changes.

Market reactions and potential shareholder wealth changes can depend on other characteristics of the business, such as debt (Ross, 1977; Leland and Pyle, 1977) and growth opportunities (Myers, 1977; Myers and Majluf, 1984). However, there is no clear consensus on their effects on stock price reactions. For example, some studies have indicated that stock prices react positively to debt issuance mainly in firms with low leverage (Cai and Zhang, 2011). This reaction implies that markets associate debt issuance as a means of control over the principal agent problem (Harris and Raviv, 199o). Other studies provide a different view and document a negative reaction (Diekerns, 1991). This market response indicates that higher debt may increase firms' bankruptcy risk (Raymar, 1993). Regarding growth opportunities, empirical studies have demonstrated that their effects on stock prices depend on their valuation (Smith and Watts, 1992; Quynh-Nhu, 2009). The lack of consensus on market interpretations could be explained by the non-linear effect of these factors on stock price reactions. For the Chilean market, these relationships are still unanswered questions and their implications are relevant for firms' corporate governance and investors, especially when inferring the possible market reaction to capital structure changes and how it may alter shareholders' wealth.

This paper analyzes the effect of ownership structure, growth opportunities and leverage on stock price reactions associated with capital structure changes in Chilean companies. Our research contributes to the empirical literature in two aspects. First, it quantifies stock price reactions to capital structure changes. These reactions measure changes in shareholder wealth. Second, it analyzes the impacts of ownership structure and the possible non-monotonous effects of debt and growth opportunities on shareholder wealth. This is relevant for investors and firms because it reveals that the stock market interprets these qualities in different ways during capital structure change processes.

We used a sample of 70 companies listed on the Santiago Stock Exchange. We studied 172 announcements of equity issuances and 319 announcements of corporate bond issuances. The results 
showed that debt and equity issuances generated positive stock prices reactions, and therefore positive effects on shareholder wealth. The figures indicate an abnormal return of $2.43 \%$ and $0.92 \%$ associated with debt and equity issuances respectively. Controlling-shareholder ownership has a negative effect on stock market reactions for debt and a positive effect on equity issuances. This suggests that the stock market responds positively to controlling shareholder ownership, associating it with tighter corporate control and firm performance. Minority shareholder ownership negatively affects stock market reactions only in the case of equity issuances, which indicates a possibility for wealth expropriation from these investors. Finally, debt and growth opportunities have non-linear effects on stock market reaction. This supports the finding that the stock market interprets these qualities in different ways during capital structure adjustments.

This paper is organized as follows. After this introduction, section 2 presents the theoretical framework for stock price reactions to capital structure changes, and its determining factors. This section also includes the research hypothesis. Section 3 presents the data and methodologies used, while section 4 shows the results. Finally, section 5 indicates the main conclusions of this article.

\section{Theoretical framework and hypothesis}

\subsection{Background on stock price reaction and shareholder wealth}

Capital structure has been widely researched, starting with the seminal works proposed by Modigliani and Miller $(1958,1963)$. Various theories have tried to explain how stock prices react to firms' capital structure adjustments, and which factors explain that reaction.

Asymmetric information theory has provided important answers. Financing security issuances can be associated with an adverse selection problem, which would explain stock price reactions. Myers and Majluf (1984) have found that equity contains higher information asymmetry, encouraging managers to issue overvalued equity. Even when managers are aligned with shareholder interests, the incentive to underinvest transmits negative information about the company that can be related to negative stock price reactions at the moment of announcement/issuance. Ross (1977), and Leland and Pyle (1977) add that managers use capital structure as a false signaling mechanism regarding the firm's quality. This moral risk problem associates positive abnormal stock returns with firms whose performance has been exaggerated, while negative abnormal returns are related to undervalued firms. However, uncertainty is reduced during issuance, generating a negative reaction in stock prices for overvalued firms.

Several studies have highlighted the downward adjustments of abnormal returns at the moment of issuance. Asquith and Mullins (1986) analyzed 266 equity issuances between 1963 and 1981 and found that stock prices experience negative abnormal returns of $2.7 \%$ during issuance. Lucas and McDonald (1990) corroborated this result, although they also documented positive abnormal returns prior to issuance. The authors note a positive correlation between information asymmetry reduction and stock price increases prior to issuance. They even warn that if abnormal returns are higher prior to announcement, the decreases during the issuance period will be less severe, thereby encouraging companies to issue equity. Mikkelson and Partch (1986) conducted an empirical study for 360 US companies, corresponding to 595 announcement events. Their results supported Asquith and Mullins (1986) and Masulis and Korwar (1986), which showed that stock price reactions were positive during periods preceding announcements and issuances, and negative at the moment of announcement and 
issuance. Other international studies have corroborated these findings for developed markets (Healy and Palepu, 1990; Eckbo and Masulis, 1992; Mitto, 1996; Burton et al., 2000; Welch, 2004; Barnes and Walker, 2006) as well as emerging markets (Leal and Amaral, 2000; De Medeiros and Matsumoto, 2005; Vithessonthi, 2008a, 2008b, 2008c; Chen and Shehu, 2009; Liu et al., 2016). Furthermore, these papers have documented that abnormal returns decrease more for equity issuances than for debt issuances.

In Chile, such evidence is scarce. Saens (1999) analyzed ADRs of Chilean companies on the NYSE and found positive abnormal returns. At the local level, Castillo (2004) analyzed 172 bond and equity issuances for the period 1993-2002. The results indicated that bond issuances do not generate significant stock price reactions, while equity issuances cause negative abnormal returns. However, the analysis does not reveal the factors that explain these reactions. According to the empirical literature, we expect that capital structure adjustments generate significant shareholder wealth changes. Therefore, we proposed this hypothesis:

H1: Corporate debt and equity issuances generate changes in shareholder wealth.

\subsection{Stock price reactions and ownership structure}

International studies have shown that the announcements and issuances of debt or equity can have significant impacts on stock prices. This process has the potential to become a means of wealth expropriation from minority shareholders to majority shareholders (Masulis, 1980).

Firms' ownership structures can be related to stock price reactions, and therefore to changes in shareholder wealth. Market perceptions of investors who buy the issued stocks would be relevant to stock price reactions. Barnes and Walker (2006) analyzed UK firms and showed that equity issuances generated both positive and negative abnormal returns. Positive reactions are concentrated in equity issuances, especially if shareholders also bought these securities. Armitage (2002) corroborated this result and added that UK companies have less concentrated ownership structures, leading to a favorable market reaction when shareholders then bought a greater proportion of issued stocks. Stock markets positively correlate firm performance with higher shareholder participation (Leland and Pyle, 1977). Armitage (2010) adds that the UK market has an institutional context that promotes investor protections. This context associates a positive stock price reaction with majority and minority shareholder ownership, inhibiting opportunities for wealth redistribution.

Emerging markets have different features. Weak legal protection for investors' rights and higher ownership concentration are some qualities that favor wealth expropriation. Vithessonthi (2008a, 2008b) and Liu et al. (2016) indicate that, for Thai and Chinese markets, respectively, equity issuances generate a positive reaction only if controlling shareholders buy these stocks. However, if minority shareholders buy securities, the stock price reaction is negative. This result may be associated with the pessimistic market perceptions surrounding conflicts of interest between controlling and minority shareholders. Chile has similar conditions to emerging markets, but there is no evidence regarding this relationship. Therefore, we propose these hypotheses:

H2a: Controlling-shareholder ownership has a positive effect on stock price reactions for equity issuances.

H2b: Minority-shareholder ownership has a negative effect on stock price reactions for equity issuances. 
Empirical evidence has demonstrated that shareholder wealth increases when firms issue corporate debt (Mikkelson and Partch, 1986; Eckbo and Masulis, 1992; Burton et al., 2000). Normally stock price reactions to corporate debt issuances are greater than the reactions experienced during equity issuances. This market reaction implies that issued debt represents a means for external monitoring on corporate governance. Myers and Majluf (1984) add that debt issuances generate more positive stock price reactions because they reduce incentives to underinvest. In the context of information asymmetry, this effect indicates that issued debt constitutes a means of control over managerial discretion and agency conflicts (Jensen and Meckling, 1976; Demsetz and Lehn, 1985; Jensen, 1986). For this reason, corporate debt is a substitute means of control in relation to ownership concentration. During debt issuances, this fact generates a stock price reaction negatively related to controlling-shareholder ownership ( $\underline{\text { Chong and López de Silanes, 2007). On the other hand, Céspedes }}$ et al. (2010) have replicated these results in Latin American countries, and added that debt is positively associated with minority shareholder ownership. In this case, debt is considered as a means of control that complements the monitoring role of minority shareholders and alleviates wealth expropriation and agency problems. As a result, stock price reactions to debt issuances can be positively related to minority-shareholder ownership. In Chile, this subject has not yet been analyzed and its implications are relevant for firms' corporate governance. Therefore, we formulate these hypotheses:

H3a: Controlling-shareholder ownership has a negative effect on stock price reactions for debt issuances.

H3b: Minority-shareholder ownership has a positive effect on stock price reactions for debt issuances.

\subsection{Role of growth opportunities and debt level}

Bayless and Chaplinsky (1996) have argued that debt or equity issuances and stock price reactions to these processes may depend on firm characteristics, such as growth opportunities (Myers and Majluf, 1984) and debt level (Ross, 1977).

Regarding growth opportunities, Chung et al. (1998) note that the quality of firm investment sets could determine stock price reactions to capital structure changes, although there is no clear consensus on this effect. Some international studies have documented that growth opportunities increase shareholder wealth. This is due to the fact that the market perceives that these opportunities are undervalued or valued enough to offset the information asymmetry cost (Dierkens, 1991; Pilotte, 1992; Denis, 1994; Burton et al., 2000; Quynh-Nhu, 2009). Thus, as growth opportunities increase, stock prices experience positive abnormal returns during debt or equity issuances. Myers and Majluf (1984), Ambarish et al. (1987) and Cooney and Kalay (1993) add that if not, stock prices will react positively only to debt issuances, while reactions to equity issuances may be negative.

Other studies have taken a different point of view. McLaughlin et al. (1998), Smith and Watts (1992), and Gombola et al. (1998) found that growth opportunities negatively affect stock price reactions. These authors support the view that markets associate greater growth opportunities with overvalued firms and higher information asymmetries (Jensen et al., 1994). In fact, Smith and Watts (1992) add that market responses are more negative for firms with greater growth opportunities than for those experiencing low levels of growth. This lack of consensus can be explained through the non-linear effect of growth opportunities on stock price reactions. This relationship might separate the negative perception associated with overvalued firms from the positive reaction linked to undervalued growth 
opportunities (Denis, 1994). In Chile, this phenomenon has not yet been studied, and it also is relevant for corporate financing decisions. We therefore formulated this hypothesis:

$\mathrm{H}_{4}$ : Growth opportunities have a non-linear effect on stock price reactions during debt and equity issuances.

Empirical evidence indicates that stock price reactions are also affected by levels of corporate debt. Diekerns (1991) and Raymar (1993) found that stock price reactions during equity issuances are positively affected by leverage. This relationship is observed mainly in firms with high debt levels. In this case, the market perceives that equity issuances are associated with information asymmetry reduction and bankruptcy risk mitigation. In this same scenario, debt issuances may generate negative stock price reactions as the stock market perceives that marginal debt increases bankruptcy risk (Raymar, 1993).

However, Quynh-Nhu (2009) found that debt levels have a negative effect on stock price reactions during equity issuances, and argued that equity has higher information asymmetry in comparison to other financing sources. In addition, Cai and Zhang (2011) support the view that stock prices react positively to leverage during debt issuances because debt controls agency conflicts. According to these findings, the firm's leverage has a non-linear effect on stock price reactions during debt or equity issuances. This kind of relationship would separate the market's perception of higher information asymmetry during equity issuances on the one hand, and agency cost control and bankruptcy risks associated with debt issuances on the other. We proposed the following hypothesis:

H5: Debt has a non-linear effect on stock price reactions during debt and equity issuances.

\section{Data and Methods}

\subsection{Data}

The data covers the period between January 1990 and December 2013, and was obtained from two sources. Information on daily stock prices, quarterly financial statements and market data was extracted from the Economatica ${ }^{\circledR}$ database, while information related to corporate bond issuances was obtained from the Financial Markets Commission of Chile (FMC). 
Table 1. Variables

\begin{tabular}{|c|c|c|}
\hline \multirow{2}{*}{\multicolumn{3}{|c|}{$\begin{array}{l}\text { Variables Definition } \\
\text { A. Shareholders wealth changes }\end{array}$}} \\
\hline & & \\
\hline AR & Abnormal Returns & Residuals obtained from the market model \\
\hline AAR & Average Abnormal Returns & AR average from each analysis window \\
\hline CAR & Cumulative average abnormal returns & AAR accumulated of each analysis window \\
\hline \multicolumn{3}{|c|}{ B. Ownership structure } \\
\hline P1 & Controlling-shareholder ownership & Percentage of shares of the first shareholder \\
\hline P5 & Minority-shareholder ownership & Percentage of shares of the fifth shareholder \\
\hline \multicolumn{3}{|c|}{ C. Leverage and growth opportunities } \\
\hline $\mathrm{GOQ}$ & Tobin's Q & Asset market value to asset book value ratio \\
\hline LEV & Leverage & Debt to total assets ratio \\
\hline \multicolumn{3}{|c|}{ D. Others control variables } \\
\hline $\mathrm{AC}$ & Agency costs & Assets turnover ratio \\
\hline FD & Financial deficit & Financial needs according to source-funding identity \\
\hline SIZE & Firm size & Natural logarithm of total assets \\
\hline $\mathrm{ROA}$ & Firm profitability & Return on assets \\
\hline TANG & Asset tangibility & Long-term assets to total assets ratio \\
\hline $\mathrm{BIS}$ & Bond issue & Natural logarithm of the bond issues in billions (pesos) \\
\hline EIS & Equity issue & Natural logarithm of the equity issue in billions (pesos) \\
\hline SLIQ & Stock liquidity & Quoted spread ratio \\
\hline
\end{tabular}

Source: Own elaboration.

The original sample is composed of 183 open-equity companies with business activity to December 31,2013 . These firms have a market presence equal to or greater than $70 \%$ over the time period, or since the company went public. In addition, we have chosen firms that have a presence of greater than $80 \%$ during the time interval of issuance processes or public offerings. Therefore, the final sample corresponds to 70 companies. Table 1 details the variables used in this study.

Cumulative abnormal return (CAR) is the dependent variable that measures stock market reactions and, therefore, shareholder wealth changes. This measure has been widely used in research based on event studies (Brown and Warner, 1985; Mikkelson and Partch, 1986; Corrado, 1989).

We used ownership structure, growth opportunities, debt, agency costs, firm size, firm profitability, asset tangibility, financial deficit, issuance size and stock liquidity as control variables.

Ownership structure was measured through the ownership of the first $\left(\mathrm{P}_{1}\right)$ and fifth $\left(\mathrm{P}_{5}\right)$ largest shareholders. According to Jensen and Meckling (1976), ownership structure can generate shareholder wealth changes as well as wealth expropriation. This topic is relevant to the Chilean market because minority investor protection is weak and ownership structures are concentrated. These conditions facilitate wealth expropriation.

Growth opportunities (GO) were measured through Tobin's Q. This variable allows control over the future growth prospects of the firm associated with financing instrument issuances (Myers, 1977; Myers and Majluf, 1984; Cooney and Kalay, 1993; Denis, 1994). 
Capital structure (LEV) was measured through the debt to total assets ratio. This measure was used by Quynh-Nhu (2009) to quantify market reactions to capital structure changes according to corporate debt levels.

Agency costs (AC) were measured by the asset turnover ratio. Jensen (1986), Ang et al. (2000) and Fleming et al. (2005) argue that this measurement is an inverse indicator of agency costs because firms with higher agency costs are less efficient in using their assets.

Financial deficit (FD) was measured based on source-funding identity. In other words, the sum of cash flows committed to dividend payments, working capital changes and capital expenses, minus operational flow. Myers and Majluf (1984) state that this variable is useful to quantify information asymmetries in stock price reactions during debt or equity issuances.

Following Rajan and Zingales (1995), we included other control variables such as firm size (SIZE), firm profitability (ROA) and asset tangibility (TANG). In addition, Castillo (2004) proposes controlling Chilean markets by issue size (IS). Finally, we used the stock liquidity (SLIQ) as a control variable due to it being a relevant factor in equity issuance (Lipson and Mortal, 2009).

\subsection{Event study methodology and econometric model}

The analysis uses two methodologies. First, we used the events study methodology to quantify the stock market reaction to the issuance announcements of corporate bonds and equity. Second, we used an econometric model to determine the factors that explain the stock market reaction.

Figure 1 shows the stages of the events study methodology. The analysis window has a median extension of 161 days for equity issuances and 157 days for corporate bond issuances. Our results also indicate that corporate bonds are issued in 46 days on average from their registration and 31 days in median, while equities are issued in 44 days on average and 35 days in median.

Figure 1 shows that window analysis is divided in five stages. The first stage corresponds to the pre-announcement period, which consists of an8o-day period between $t=-90$ to $t=-10$. The potential stock price reaction at this stage could reveal whether the stock market is receiving relevant information from firms or from any other specific agent. However, we expect this reaction to be null as Chilean Stock Market Laws prevent companies from disclosing information about securities issuance processes before registration.

The second stage corresponds to announcement, which is defined as $\mathrm{t}=\mathrm{O}$. According to $\underline{\text { Castillo }}$ (2004), this period ranges from $t=-10$ to $t=+10$. The announcement is defined as a securities issuance approval by the FMC. Chilean stock market regulations only allow firms to announce or disclose information regarding such processes once they have been registered and authorized by the FMC.

The third stage is the post-announcement period, which differs according to the kind of security issued. The fourth stage corresponds to the issuance period, which ranges from $\mathrm{t}=+3 \mathrm{O}$ to $\mathrm{t}=+4 \mathrm{O}$ for equity issuances, and $t=+26$ to $t=+36$ for bond issuances. Finally, the analysis window concludes with the post-issuance period. 
Figure 1. Temporary analysis window for issuances

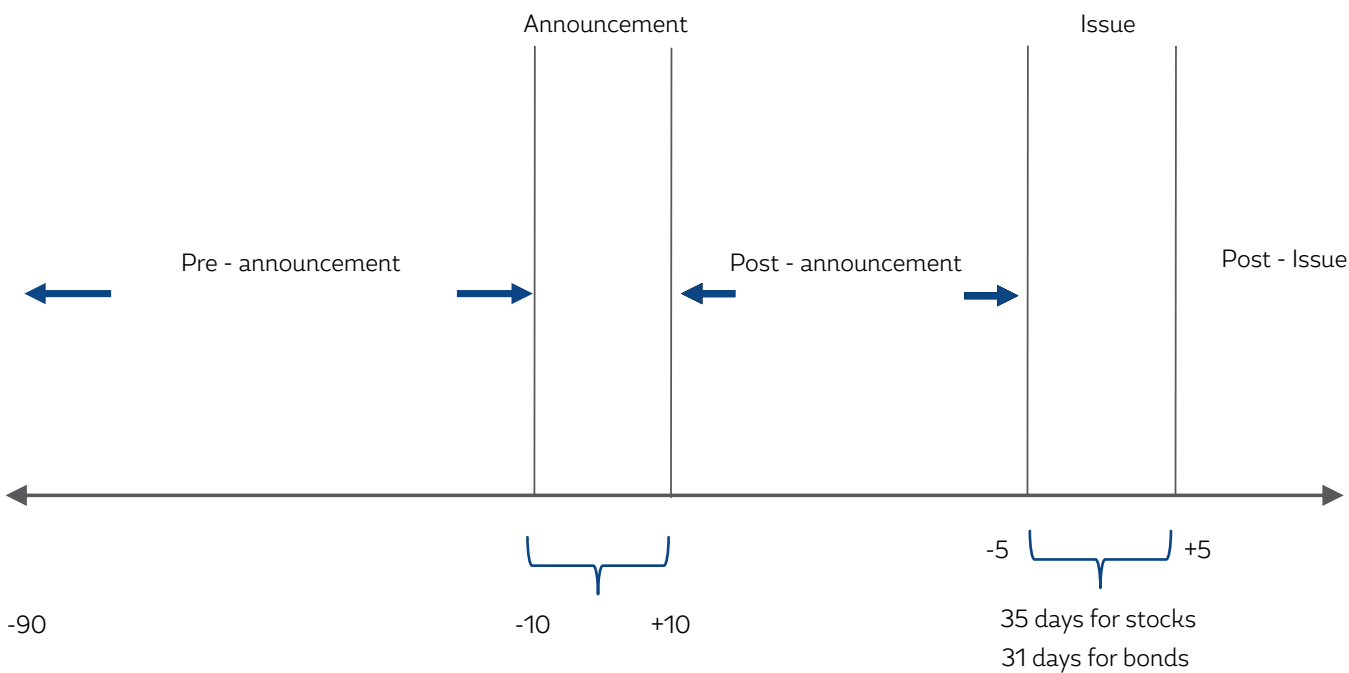

Source: Own elaboration.

In accordance with Mikkelson and Partch (1986) and MacKinlay (1997), we measured stock price reactions to capital structure changes for each stage. The market model was used to determine this reaction on shareholder wealth change. The expected return of security $i$ is:

$$
E\left(r_{i t}\right)=\beta_{0}+\beta_{1} r_{m t}
$$

Where $r_{m t}$ is daily market returns measured by the General Stock Price Index (IGPA), while $\beta_{0}$ and $B_{1}$ are the OLS coefficients. The market reaction is measured as:

$$
A R_{i t}=r_{i t}-E\left(r_{i t}\right)
$$

Where $A R_{i t}$ is the daily abnormal return of security $i$ in period $t, r_{i t}$ is the effective return of security $i$ in period $t$ and $E\left(r_{i t}\right)$ is the expected return of security $i$ in period $t$ based on the market model. Thus, abnormal returns correspond to market model residuals:

$$
A A R_{i t}=\frac{1}{T} \sum_{t}^{T} A R_{i t}
$$

Where $A A R_{i t}$ is the average abnormal return of firm $i$ in period $t$ and $T$ is the size of each stage. Finally, we calculated this accumulated measure:

$$
C A R_{i t}=\sum_{t}^{T} A A R_{i t}
$$

Where $C A R_{i t}$ is the cumulative average abnormal return of firm $i$ in period $t$. These measures were applied both to debt and equity issuance announcements.

Following Corrado (1989), Corrado and Zivney (1992) and Brown and Warner (1985), we used a traditional $t$-student test to determine the statistical significance for AARs. However, the significance of CARs was measured through this test: 


$$
t_{C A R}=\frac{C A R_{L}}{\sqrt{T * V(A A R)}}
$$

Where $V(A A R)$ is the variance of $A A R$ and $C A R_{L}$ is the cumulative average of the abnormal return of window $L$. This statistic was used to measure the significance of CARs across different windows, especially if they showed different behavior. In both cases, the null hypothesis indicates that both $A A R$ and CAR are equal to zero, which shows that there are no significant shareholder wealth changes.

Finally, we applied instrumental variable (IV) regression to each stage and to the full process. From this regression, we focused on the effects of ownership structure, capital structure and growth opportunities on stock price reactions. The empirical model is:

$$
\begin{aligned}
& C A R_{i s}=\beta_{0}+\beta_{1} P 1_{i s}+\beta_{2} P 5_{i s}+\beta_{3} G O_{i s}+\beta_{4} G O_{i s}{ }^{2}+\beta_{5} L E V_{i s}+\beta_{6} L E V_{i s}{ }^{2} \\
& +\beta_{7} A C_{i s}+\beta_{8} F D_{i s}+\beta_{9} S_{I Z E_{i s}}+\beta_{10} R O A_{i s}+\beta_{11} T A N G_{i s}+\beta_{12} I S_{i s} \\
& +\beta_{13} \text { SLIQ }_{\text {is }}+\delta_{0} \text { DSector }{ }_{i}+\delta_{1} \text { DTime }+\delta_{2} \text { DStage }+\varepsilon_{i s}
\end{aligned}
$$

Where $C A R_{\text {is }}$ is the $C A R$ associated with issuances developed by firm $i$ in stage $s$. This measure was calculated in order to obtain one observation per stage during the event and another for the whole process. Each observation was matched with quarterly data for issuing firms in order to estimate regression (6). Within the control variables, $P_{1}$ is controller-shareholder ownership, $P_{5}$ is minority-shareholder ownership, GO represents the growth opportunities measured by Tobin's $\mathrm{Q}$, LEV is the firm's capital structure, AC represents agency costs, FD is the financial deficit, SIZE indicates firm size, ROA measures firm profitability, TANG is asset tangibility, IS is issuance size and SLIQ represents the stock liquidity. Note that $G^{2}$ and $L E V^{2}$ measure the potential non-linear effect of growth opportunities and debt level on stock price reactions, respectively. We used robust variances to correct for heteroskedasticity patterns. In addition, dummy variables were included to control the differences across economic sectors (DSector), respective emission trimester (DTime) and stage of analysis (DStage). The IV estimator was used due to the endogeneity problem between stock market reaction, measured through $C A R_{i s}$, and issuance size. According to Myers and Majluf (1984) and Baker and Wurgler (2002), the equity (debt) issuance depends on stock prices, in this case on CAR. To correct this endogeneity problem we used the financial expense ratio, defined as operational income to financial expense ratio, and current liquidity, expressed as current assets to current liability ratio. These instruments are correlated with issuance size, but not with CAR. Finally, we used the Sargan test to evaluate the instrumental overidentification of the models.

\section{Empirical results}

\subsection{Statistical analysis of debt and equity issuances in Chile}

Table 2 presents information on corporate bond issuances registered by firms between 1990 and 2013. The total number of events associated with debt issuances corresponds to 319 authorized, issued and completed records. Bonds denominated in Unidad de Fomento (hereafter referred to as U.F.) represent $91.90 \%$ of corporate bond issuances in Chile, followed by issuances denominated in US dollars (5.33\%) and Chilean pesos (3.76\%). During the nineties, most issuances were denominated in U.F. due to the high inflation rates that characterized this period. Issuances denominated in pesos 
became recurrent during periods of lower inflation. This context is associated with the reduction in U.F. bond rates from $6.93 \%$ in the late 1990 s to $3.97 \%$ in 2013 .

On average, corporate bond maturity was 10.36 years. Debt denominated in U.F. had an average maturity of 15.90 years, while issuances denominated in dollars and pesos do not exceed 10 years. Corporate bond issuances had specific motivations. 55.49\% of bond issuances were made to replace existing liabilities and $30.72 \%$ were made to finance new investments. Substitutions for foreign currency liabilities $(6.27 \%)$ and short/medium-term liabilities (5.64\%) were less common motivations. Finally, we did not observe a clear pattern regarding the volume and number of bond issuances.

Table 2. Corporate debt issuances in Chile, 1990-2013

\begin{tabular}{|c|c|c|c|c|c|c|c|c|c|c|c|}
\hline \multirow{2}{*}{ Year } & \multirow{2}{*}{ Unit } & \multirow{2}{*}{$\begin{array}{l}\text { Registered } \\
\text { Amount } \\
\text { (thousands) }\end{array}$} & \multirow{2}{*}{$\begin{array}{l}\text { Average } \\
\text { issue rate }\end{array}$} & \multirow{2}{*}{$\begin{array}{l}\text { Average } \\
\text { maturity }\end{array}$} & \multicolumn{6}{|c|}{ Reason for issuance } & \multirow{2}{*}{$\begin{array}{c}\text { Total } \\
\text { Issues }\end{array}$} \\
\hline & & & & & SSM & GP & $\mathrm{FI}$ & OF & SLF & LR & \\
\hline 1990 & U.F. & 4950 & 6.84 & 16.40 & 4 & 0 & 1 & 0 & 0 & 0 & 5 \\
\hline 1991 & U.F. & 7175 & 6.50 & 14.25 & 2 & 0 & 2 & 0 & 4 & 0 & 8 \\
\hline 1992 & U.F. & 1950 & 6.25 & 17.00 & 1 & 0 & 1 & 0 & 0 & 0 & 2 \\
\hline 1993 & - & - & - & - & - & - & - & - & - & - & - \\
\hline 1994 & U.F. & 5300 & 6.17 & 13.33 & 2 & 0 & 4 & 0 & 0 & 0 & 6 \\
\hline 1995 & - & - & - & - & - & - & - & - & - & - & - \\
\hline 1996 & - & - & - & - & - & - & - & - & - & - & - \\
\hline 1997 & USS & ND & 6.00 & 9.00 & 0 & 0 & 0 & 6 & 0 & 0 & 6 \\
\hline 1998 & U.F. & 2200 & 6.75 & 16.50 & 0 & 0 & 2 & 0 & 0 & 0 & 2 \\
\hline \multirow{2}{*}{1999} & USȘ (*) & 100000 & Libor+1.5 & 6 & 0 & 0 & 0 & 0 & 0 & 2 & 2 \\
\hline & U.F. & 18500 & 6.93 & 22.29 & 0 & 0 & 5 & 0 & 0 & 2 & 7 \\
\hline 2000 & U.F. & 22056 & 7.15 & 16.94 & 2 & 0 & 4 & 5 & 0 & 6 & 17 \\
\hline \multirow{2}{*}{2001} & U.F. & 36830 & 6.18 & 12.56 & 3 & 0 & 4 & 2 & 0 & 7 & 16 \\
\hline & USȘ & 100000 & 8.00 & 5.00 & 0 & 0 & 0 & 0 & 0 & 3 & 3 \\
\hline 2002 & U.F. & 44608 & 5.86 & 15.76 & 4 & 0 & 0 & 0 & 0 & 4 & 8 \\
\hline 2003 & U.F. & 61300 & 5.08 & 12.25 & 0 & 0 & 2 & 0 & 0 & 12 & 14 \\
\hline 2004 & U.F & 24650 & 4.41 & 15.56 & 0 & 0 & 0 & 0 & 0 & 7 & 7 \\
\hline 2005 & U.F. & 85250 & 3.56 & 15.29 & 0 & 0 & 4 & 0 & 0 & 22 & 26 \\
\hline 2006 & U.F & 49600 & 3.92 & 18.46 & 0 & 0 & 0 & 2 & 0 & 10 & 12 \\
\hline \multirow{2}{*}{2007} & U.F & 76800 & 3.55 & 15.53 & 0 & 0 & 7 & 3 & 0 & 10 & 20 \\
\hline & USȘ & 600000 & & 20.00 & 0 & 0 & 2 & 0 & 0 & 0 & 2 \\
\hline \multirow{3}{*}{2008} & U.F & 149300 & 4.01 & 16.34 & 0 & 0 & 20 & 2 & 0 & 15 & 37 \\
\hline & $\operatorname{USȘ}\left({ }^{*}\right)$ & 565680 & Libor +2.53 & 8.33 & 0 & 0 & 2 & 0 & 0 & 1 & 3 \\
\hline & S & 74800000 & 7.50 & 5.00 & 0 & 0 & 0 & 0 & 0 & 1 & 1 \\
\hline \multirow{3}{*}{2009} & U.F. & 138500 & 4.11 & 14.93 & 0 & 0 & 14 & 0 & 0 & 18 & 32 \\
\hline & USȘ & 196000 & 8.00 & 10.00 & 0 & 0 & 1 & 0 & 0 & 0 & 1 \\
\hline & \$ & 383740000 & 6.40 & 5.40 & 0 & 0 & 3 & 0 & 0 & 2 & 5 \\
\hline \multirow{2}{*}{2010} & \$ & 106030000 & 7.13 & 5.00 & 0 & 0 & 0 & 0 & 0 & 2 & 2 \\
\hline & U.F. & 43000 & 5.92 & 15.80 & 0 & 0 & 5 & 0 & 0 & 10 & 15 \\
\hline 2011 & U.F. & 41800 & 3.74 & 15.73 & 0 & 0 & 7 & 0 & 0 & 8 & 15 \\
\hline \multirow{2}{*}{2012} & U.F. & 99050 & 4.02 & 18.12 & 0 & 0 & 7 & 0 & 0 & 19 & 26 \\
\hline & \$ & 101200000 & 6.50 & 6.00 & 0 & 0 & 1 & 0 & 0 & 1 & 2 \\
\hline \multirow{2}{*}{2013} & U.F. & 30300 & 3.97 & 15.07 & 0 & 2 & 0 & 0 & 0 & 13 & 15 \\
\hline & \$ & 96300000 & 6.50 & 6.00 & 0 & 0 & 0 & 0 & 0 & 2 & 2 \\
\hline
\end{tabular}




\begin{tabular}{|c|c|c|c|c|c|c|c|c|c|c|c|}
\hline \multirow{2}{*}{ Year } & \multirow{2}{*}{ Unit } & \multirow{2}{*}{$\begin{array}{l}\text { Registered } \\
\text { Amount } \\
\text { (thousands) }\end{array}$} & \multirow{2}{*}{$\begin{array}{l}\text { Average } \\
\text { issue rate }\end{array}$} & \multirow{2}{*}{$\begin{array}{l}\text { Average } \\
\text { maturity }\end{array}$} & \multicolumn{6}{|c|}{ Reason for issuance } & \multirow{2}{*}{$\begin{array}{l}\text { Total } \\
\text { Issues }\end{array}$} \\
\hline & & & & & SSM & GP & $\mathrm{FI}$ & OF & SLF & LR & \\
\hline \multirow{3}{*}{$\begin{array}{l}1990- \\
2013\end{array}$} & U.F & 47156 & 5.25 & 15.90 & 18 & 2 & 89 & 14 & 4 & 163 & 290 \\
\hline & USȘ & 312336 & 7.33 & 9.72 & 0 & 0 & 5 & 6 & 0 & 6 & 17 \\
\hline & Ș & 152414000 & 6.81 & 5.48 & 0 & 0 & 4 & 0 & 0 & 8 & 12 \\
\hline
\end{tabular}

$\left(^{*}\right)$ It includes corrections for issuances at the Libor rate of 180 days. (N/A) indicates information not available. $\left({ }^{* *}\right)$ Issuances proposed: substitution of short-medium term liabilities (SSM), general purposes (GP), financing investment (FI), company-owned financing (OF), substitution of local currency and foreign liabilities (SLF) and liability replacement (LR). Source: own elaboration

Table 3 shows the equity issuances summary across 172 events. Equity issuances fluctuated between $0.77 \%$ and $284.65 \%$ of firms' capital, with an average of $54.61 \%$. Regardless of the number of stocks issued, there was no clearly defined pattern in issuance size. However, the largest number of issuances was concentrated in the periods 1997-1998 and 2008-2009, which coincided with the Asian and Subprime crises respectively. It should be noted that $73.62 \%$ of the issuances were issued by manufacturing firms, followed by real estate, banking and financial service sector firms.

Table 3. Equity issuances in Chile, 1990-2013

\begin{tabular}{|c|c|c|c|c|c|}
\hline Years & Issued capital (MȘ') & Factor & $\begin{array}{l}\text { Stocks subscribed } \\
\text { (Thousands) }\end{array}$ & Amount (MȘ') & Total Issue \\
\hline 1990 & - & - & & - & 0 \\
\hline 1991 & 6.961 .962 & 0,0077 & 53.263 & 1.288 .969 & 1 \\
\hline 1992 & 1.317 .005 & 0,1197 & 131.703 & 79.156 .498 & 5 \\
\hline 1993 & 7.081 .055 & 0,2467 & 963.497 & 279.241 .022 & 9 \\
\hline 1994 & 15.610 .423 & 0,1896 & 954.192 & 159.878 .113 & 4 \\
\hline 1995 & 19.610 .936 & 0,2513 & 4.525 .975 & 359.514 .639 & 14 \\
\hline 1996 & 27.268 .990 & 2,8465 & 25.245 .676 & 133.944 .627 .888 & 9 \\
\hline 1997 & 22.255 .806 & 0,1966 & 4.336 .872 & 529.058 .991 & 11 \\
\hline 1998 & 2.619 .395 & 0,2407 & 529.153 & 249.582 .203 & 9 \\
\hline 1999 & 22.911 .895 & 0,3618 & 5.412 .243 & 304.612 .240 & 11 \\
\hline 2000 & 28.914 .569 & 0,3635 & 7.645 .426 & 678.063 .590 & 7 \\
\hline 2001 & 8.843 .029 & 0,1396 & 821.778 & 48.239 .850 & 2 \\
\hline 2002 & 9.812 .098 & 2,1460 & 3.346 .883 & 88.148 .863 & 3 \\
\hline 2003 & 39.904 .270 & 2,6301 & 32.130 .491 & 1.853 .215 .351 & 5 \\
\hline 2004 & 15.110 .738 & 0,2201 & 2.838 .219 & 490.423 .690 & 7 \\
\hline 2005 & 37.353 .382 & 0,2755 & 4.931 .481 & 762.795 .945 & 7 \\
\hline 2006 & 2.971 .932 & 0,2465 & 437.730 & 95.836 .208 & 4 \\
\hline 2007 & 22.503 .970 & 0,0969 & 1.719 .906 & 534.316 .933 & 9 \\
\hline 2008 & 34.298 .179 & 0,2249 & 4.747 .946 & 770.567 .022 & 9 \\
\hline 2009 & 20.690 .392 & 0,2496 & 6.822 .770 & 475.091 .945 & 12 \\
\hline 2010 & 11.968 .903 & 0,2612 & 3.661 .224 & 20.337 .657 .183 & 7 \\
\hline 2011 & 37.657 .441 & 0,3382 & 10.747 .355 & 1.371 .807 .825 & 11 \\
\hline 2012 & 5.796 .339 & 0,6691 & 1.804 .052 & 1.103.962.191 & 6 \\
\hline 2013 & 69.102 .084 & 0,2387 & 26.710 .725 & 171.488 .009 .664 & 10 \\
\hline Mean 1990-2013 & 20.459 .339 & 0,5461 & 6.550 .135 & 14.609 .326 .723 & 7.17 \\
\hline Total 1990-2013 & 470.564 .793 & - & 150.653 .100 & 336.014 .514 .635 & 172 \\
\hline
\end{tabular}

Source: Own elaboration 


\subsection{Stock market reaction and shareholder wealth changes}

Table 4 shows the event analysis results. These results consider 172 and 319 events, associated with equity and bond issuances respectively. Corporate bonds and equity issuances generated significant stock price reactions, and therefore relevant shareholder wealth changes. Corporate debt issuances caused an abnormal increase of $2.43 \%$ on stock prices, which was higher than $0.92 \%$ experienced in equity issuances. According to previous studies, these results show that information asymmetry content is potentially greater in equity issuances (Myers and Majluf, 1984; Mikkelson and Partch, 1986; Asquith and Mullins, 1986; Masulis and Korwar, 1986; Leal and Amaral, 2000; De Medeiros and Matsumoto, 2005). Finally, these results support hypothesis H1.

Changes in shareholder wealth showed similar patterns in both kinds of issuances. The preannouncement and post-announcement periods showed positive AARs and CARs. These facts materialized mainly during the period prior to issuances (post-announcement). Despite this, equity issuances did not significantly affect stock prices during the pre-announcement period. Debt issuances generated an accumulated abnormal return of $0.89 \%$. This result is evidence that, in Chile, debt issuances are a signaling mechanism that transmits information to the markets prior to FMC authorization.

Table 4. t-tests for market reactions/shareholder wealth, percentage

\begin{tabular}{l|c|c|c|l|c|c|c|c}
\multirow{2}{*}{$\begin{array}{c}\text { Stage at analysis } \\
\text { window }\end{array}$} & \multicolumn{9}{|c}{ Debt issue } & \multicolumn{5}{c}{ Equity issue } \\
\cline { 2 - 10 } & AAR & $t$-statistics & CAR & $t$-statistics & AAR & $t$-statistics & CAR & $t$-statistics \\
\cline { 2 - 10 } & 0.889 & $(1.92)^{*}$ & 0.889 & $(1.84)^{*}$ & 0.360 & $(0.43)$ & 0.360 & $(0.74)$ \\
\hline Pre-announcement & -0.772 & $(-1.69)^{*}$ & 0.117 & $(0.94)$ & -0.480 & $(-0.75)$ & -0.120 & $(-0.27)$ \\
\hline Announcement & 3.156 & $(5.42)^{* * *}$ & 3.273 & $(3.85)^{* * *}$ & 2.234 & $(4.27)^{* * *}$ & 2.114 & $(3.77)^{* * *}$ \\
\hline Post-announcement & -0.945 & $(-1.89)^{*}$ & 2.328 & $(2.97)^{* * *}$ & -0.778 & $(-1.85)^{*}$ & 1.336 & $(2.36)^{* *}$ \\
\hline Issuance & 0.102 & $(1.03)$ & 2.430 & $(2.67)^{* * *}$ & -0.415 & $(-0.91)$ & 0.921 & $(1.99)^{* *}$ \\
\hline Post-Issuance & & & & & & & &
\end{tabular}

Superscripts $* * *, * * *$ indicate statistical significance at 1,5 , and 10 percent, respectively. Source: Own elaboration.

The AAR and CAR figures were generated mainly in the post-announcement period. This also supports the occurrence of significant shareholder wealth changes. CARs on debt and equity issuances were $3.27 \%$ and $2.11 \%$, respectively. These results are consistent with international empirical evidence (Mikkelson and Partch, 1986; Asquith and Mullins, 1986; Masulis and Korwar, 1986; Healy and Palepu, 1990; Eckbo and Masulis, 1992; Mitto, 1996; Burton et al., 2000; Welch, 2004; De Medeiros and Matsumoto, 2005; Chen and Shehu, 2009; Liu et al., 2016).

The announcement and issuance periods were characterized by negative AARs. During the announcement period, debt issuances generated a significant AAR equal to $-0.77 \%$, while equity issuances generated a non-significant AAR of -0.48\%. The fall experienced during the issuance period was comparatively greater than that experienced during the announcement period. Both debt and equity issuances generated negative and significant AARs equal to - $0.94 \%$ and $-0.77 \%$, respectively. These results suggest that downward adjustments in stock prices occurring during the issuance period reduce information asymmetry more than those occurring during the announcement period. Finally, positive AARs generated between the announcement and the issuance periods support the positive CARs for all processes. 


\subsection{What factors can explain shareholder wealth changes?}

Table 5 presents a statistical analysis of the variables. Chilean firms have high ownership concentration, where controlling shareholders own on average $61.64 \%$ of company shares. This characteristic is common in civil law countries like Chile, where weak legal protections for investor rights motivates controllers to concentrate ownership as a way to protect their investments. The fifth-largest shareholders only concentrate $3.38 \%$. Due to the weak legal protections that the Chilean market offers its investors, it is probable that discretionary decisions by controllers could serve to expropriate wealth from these shareholders.

Other average results showed that asset turnover for firms was o.66, while $58.93 \%$ of the assets corresponded to long-term investments (tangibility). Regarding firm performance, the results indicated that the average return on assets was $14.39 \%$, which is consistent with future growth opportunities described by Tobin's $Q$ equal to 7.70 .

Table 5. Summary statistics for Chilean firm

\begin{tabular}{|c|c|c|c|}
\hline \multicolumn{2}{|r|}{ Variables } & Mean & S.D. \\
\hline \multicolumn{4}{|c|}{ A. Ownership structure } \\
\hline P1 & Controlling-shareholder share (\%) & 61.64 & 29.56 \\
\hline P5 & Minority-shareholder share (\%) & 3.38 & 2.82 \\
\hline \multicolumn{4}{|c|}{ B. Leverage and growth opportunities } \\
\hline GOQ & Tobin's Q & 7.70 & 15.09 \\
\hline LEV & Leverage (\%) & 62.73 & 35.51 \\
\hline \multicolumn{4}{|c|}{ C. Others control variables } \\
\hline$A C$ & Agency costs & 0.66 & 0.35 \\
\hline FD & Financial deficit (billions pesos) & 9.2 & 27.59 \\
\hline SIZE & Firm size (billions pesos) & 499.78 & 556.35 \\
\hline $\mathrm{ROA}$ & Firm profitability $(\%)$ & 14.39 & 21.46 \\
\hline TANG & Asset tangibility (\%) & 58.93 & 74.21 \\
\hline BIS & Bonds issue (billions pesos) & 17576.84 & 14857.32 \\
\hline EIS & Equity issue (billions pesos) & 14609.33 & 16282.34 \\
\hline SLIQ & Stock Liquidity (\%) & 4.02 & 23.49 \\
\hline
\end{tabular}

Source: Own elaboration.

On average, funding requirements amounted to $\$ 9.2$ billion. In general, the firms financed their investments and/or their financial needs mostly through debt. The total debt to total assets ratio was $62.73 \%$ on average. This could be related to the fact that bond issuances are greater than equity issuances.

Tables 6 and 7 present the results of model (6) for corporate debt and equity issuances, respectively. In both cases, the Hausman test indicates that the OLS estimator is biased due to an endogeneity problem caused by the size of issuance. In all cases, the IV estimator is better than OLS. The Sargan test indicates that the models are overidentified and the instruments used are exogenous.

Table 6 shows that some control variables have the expected effects, mainly in the pre-announcement and post-announcement periods. According to Table 6, variables such as firm size (SIZE), returns on 
assets (ROA), asset tangibility (TANG) and financial deficits (FD) had a positive and significant effect on stock price reactions. The results indicate that markets react favorably to debt issuance when firms are large, profitable and have investments in long-term assets. Regarding the effect of financial deficits (FD), the positive relationship observed suggests that the market associates less information asymmetry content to debt issuances (Myers and Majluf, 1984). Bond issue size (BIS) had a significant negative effect. Asset turnover ratio, as an agency costs (AC) inverse measure, had a significant and negative effect on stock price reactions. When firms have higher agency costs, their stock prices react positively because the debt issued is perceived as a control means on agency conflicts (Jensen, 1986; Ang et al., 2000). Finally, stock liquidity (SLIQ) variables had a positive and significant impact on CAR. This result suggests that higher quoted spread (lower stock liquidity) generates a positive reaction on stock prices for corporate debt issuances (Lipson and Mortal, 2009).

Ownership structure had a significant effect on stock price reactions. Controlling shareholder ownership ( $\mathrm{P} 1$ ) had a negative and significant effect, which supports hypothesis $\mathrm{H}_{3} \mathrm{a}$. These findings suggest that when firms issue debt, the market perceives debt as a substitute means of control in relation to the monitoring role of ownership concentration (Jensen and Meckling, 1976; Demsetz and Lehn, 1985; Jensen, 1986; Chong and López de Silanes, 2007; Céspedes et al., 2010). On the other hand, minority shareholder ownership $\left(\mathrm{P}_{5}\right)$ had a positive but not significant effect on stock price reactions. This result contradicts hypothesis $\mathrm{H}_{3} \mathrm{~b}$. Thus, there is no significant evidence to support the hypothesis that stock price reactions can be explained by the complementary relationship between debt issued and minority shareholder ownership.

Table 6. 2SLS regression model for shareholder wealth changes during debt issuance processes

\begin{tabular}{|c|c|c|c|c|c|c|}
\hline \multirow{3}{*}{$\begin{array}{l}\text { Explanatory } \\
\text { variables }\end{array}$} & \multicolumn{6}{|c|}{ Dependent variable: Stock price reaction/shareholder wealth changes measured by CAR } \\
\hline & \multicolumn{5}{|c|}{ Stage at analysis window } & \multirow[b]{2}{*}{ Full process } \\
\hline & $\begin{array}{c}\text { Pre- } \\
\text { announcement }\end{array}$ & Announcement & $\begin{array}{c}\text { Post- } \\
\text { announcement }\end{array}$ & Issue & Post-Issue & \\
\hline \multirow{2}{*}{ Constant } & 0.0112 & $0.0551^{* * *}$ & 0.0055 & $0.0791^{* * *}$ & $0.0632^{* *}$ & $0.1119 * * *$ \\
\hline & $(0.48)$ & $(3.27)$ & $(0.41)$ & $(3.88)$ & $(2.27)$ & $(2.81)$ \\
\hline \multicolumn{7}{|c|}{ Ownership structure } \\
\hline \multirow{2}{*}{$\begin{array}{l}\text { Controller- } \\
\text { shareholder }\end{array}$} & $-0.0104^{* * *}$ & 0.0003 & $-0.0244^{* * *}$ & $-0.0083^{* * *}$ & $0.0095 * * *$ & $-0.0322 * * *$ \\
\hline & $(-3.09)$ & $(0.91)$ & $(-3.39)$ & $(-2.92)$ & $(3.13)$ & $(-2.64)$ \\
\hline \multirow{2}{*}{$\begin{array}{l}\text { Minority- } \\
\text { shareholder }\end{array}$} & $0.0060^{* *}$ & 0.0007 & $0.0108^{* *}$ & $-0.0142^{* * *}$ & 0.0051 & 0.0010 \\
\hline & $(2.04)$ & $(0.66)$ & $(2.47)$ & $(-3.18)$ & $(0.89)$ & $(0.45)$ \\
\hline \multicolumn{7}{|c|}{ Leverage and growth opportunities } \\
\hline \multirow{2}{*}{ Tobin's Q } & $0.0084^{* * *}$ & -0.0007 & $0.0110^{* * *}$ & $-0.0023^{* *}$ & $0.0072^{* * *}$ & $0.0238^{* * *}$ \\
\hline & $(3.49)$ & $(-0.29)$ & $(3.06)$ & $(-2.01)$ & $(3.19)$ & $(3.41)$ \\
\hline \multirow{2}{*}{$\begin{array}{l}\text { Tobin's Q } \\
\text { squared }\end{array}$} & $-0.0006^{* * *}$ & -0.0001 & $-0.0009^{* * *}$ & -0.0002 & $-0.0006^{* *}$ & $-0.0023^{* * *}$ \\
\hline & $(-2.67)$ & $(-0.51)$ & $(-3.15)$ & $(-0.74)$ & $(-2.51)$ & $(-2.89)$ \\
\hline \multirow{2}{*}{ Leverage } & $0.0248^{* * *}$ & 0.0019 & $0.0181^{* * *}$ & $-0.0104^{* *}$ & $0.0132^{* * *}$ & $0.0441^{* * *}$ \\
\hline & $(3.11)$ & $(1.08)$ & $(3.45)$ & $(-1.98)$ & $(2.73)$ & $(2.99)$ \\
\hline \multirow{2}{*}{$\begin{array}{l}\text { Leverage } \\
\text { squared }\end{array}$} & $-0.0021^{* * *}$ & 0.0001 & $-0.0019 * *$ & 0.0007 & $-0.0022^{* *}$ & $-0.0051^{* * *}$ \\
\hline & $(-2.91)$ & $(0.45)$ & $(-2.56)$ & $(0.99)$ & $(-2.49)$ & $(-2.77)$ \\
\hline \multicolumn{7}{|c|}{ Other control variables } \\
\hline \multirow{2}{*}{ Agency costs } & $-0.0223^{* *}$ & 0.0052 & $-0.0321^{* *}$ & 0.0023 & $-0.0211^{* *}$ & $-0.0465 * *$ \\
\hline & $(-1.97)$ & $(0.88)$ & $(-2.53)$ & $(0.54)$ & $(-2.03)$ & $(-2.48)$ \\
\hline
\end{tabular}




\begin{tabular}{|c|c|c|c|c|c|c|}
\hline \multirow{3}{*}{$\begin{array}{l}\text { Explanatory } \\
\text { variables }\end{array}$} & \multicolumn{6}{|c|}{ Dependent variable: Stock price reaction/shareholder wealth changes measured by CAR } \\
\hline & \multicolumn{5}{|c|}{ Stage at analysis window } & \multirow[b]{2}{*}{ Full process } \\
\hline & $\begin{array}{c}\text { Pre- } \\
\text { announcement }\end{array}$ & Announcement & $\begin{array}{c}\text { Post- } \\
\text { announcement }\end{array}$ & Issue & Post-Issue & \\
\hline \multirow{2}{*}{ Financial deficit } & $0.0191^{* *}$ & -0.0084 & $0.0283^{* * *}$ & -0.0052 & $0.0162^{*}$ & $0.0458^{* * *}$ \\
\hline & $(2.16)$ & $(-0.93)$ & (3.11) & $(-0.28)$ & $(1.79)$ & $(2.61)$ \\
\hline \multirow{2}{*}{ Firm size } & $0.0053^{* *}$ & -0.0011 & $0.0047^{*}$ & 0.0024 & 0.0013 & $0.0072^{* *}$ \\
\hline & $(2.10)$ & $(-0.59)$ & $(1.71)$ & $(1.27)$ & $(0.82)$ & (1.98) \\
\hline \multirow{2}{*}{$\begin{array}{l}\text { Firm } \\
\text { profitability }\end{array}$} & 0.0004 & -0.0013 & $0.0302^{* *}$ & 0.0011 & $0.0113^{*}$ & $0.0195^{* *}$ \\
\hline & $(0.33)$ & $(-0.65)$ & $(2.51)$ & $(1.03)$ & $(1.69)$ & $(2.29)$ \\
\hline \multirow{2}{*}{ Asset tangibility } & $0.0169^{* *}$ & -0.0022 & $0.0227^{* *}$ & 0.0010 & 0.0056 & $0.0376^{* *}$ \\
\hline & $(2.31)$ & $(-0.47)$ & $(2.44)$ & $(0.26)$ & $(0.49)$ & $(2.21)$ \\
\hline \multirow{2}{*}{ Issue size } & -0.0058 & $-0.0889 * * *$ & 0.0121 & 0.0033 & 0.0017 & $-0.0357^{* *}$ \\
\hline & $(-0.95)$ & $(-3.14)$ & $(1.14)$ & $(0.51)$ & $(0.36)$ & $(-2.03)$ \\
\hline \multirow{2}{*}{ Stock liquidity } & $0.0357^{* * *}$ & 0.0028 & $0.0211^{* * *}$ & 0.0039 & 0.0015 & $0.0392^{* * *}$ \\
\hline & (3.18) & $(1.12)$ & $(2.75)$ & $(1.03)$ & $(0.89)$ & $(2.67)$ \\
\hline $\begin{array}{l}\text { Adjusted } \\
\text { R-squared }\end{array}$ & 0.39 & 0.21 & 0.43 & 0.31 & 0.29 & 0.41 \\
\hline Global F-test & $(51.21)^{* * *}$ & $(48.57)^{* * *}$ & $(60.58)^{* * *}$ & $(46.19)^{* * *}$ & $(55.10)^{* * *}$ & $(49.35)^{* * *}$ \\
\hline White test & $(21.42)^{* * *}$ & $(26.02)^{* * *}$ & $(19.49)^{* * *}$ & $(27.36)^{* * *}$ & $(20.35)^{* * *}$ & $(16.98)^{* * *}$ \\
\hline Hausman test & $(28.39)^{* * *}$ & $(35.23)^{* * *}$ & $(38.01)^{* * *}$ & $(30.22)^{* * *}$ & $(37.75)^{* * *}$ & $(32.06)^{* * *}$ \\
\hline Sargan test & $(46.01)$ & (40.93) & (37.56) & (39.61) & $(41.35)$ & (36.19) \\
\hline Sector dummy & Yes & Yes & Yes & Yes & Yes & Yes \\
\hline Time dummy & Yes & Yes & Yes & Yes & Yes & Yes \\
\hline Stage dummy & No & No & No & No & No & Yes \\
\hline $\begin{array}{l}\text { Robust } \\
\text { variance }\end{array}$ & Yes & Yes & Yes & Yes & Yes & Yes \\
\hline Observations & 319 & 319 & 319 & 319 & 319 & 1595 \\
\hline
\end{tabular}

Superscripts ${ }^{* * *},{ }^{*},{ }^{*}$ indicate statistical significance at 1,5 , and 10 percent, respectively.

Source: Own elaboration.

According to previous studies, growth opportunities (GO) had a positive and significant effect on stock price reactions (Myers and Majluf, 1984; Ambarish et al., 1987; Dierkens, 1991; Pilotte, 1992; Denis, 1994; Burton et al., 2000; Quynh-Nhu, 2009). This suggests that the growth opportunities of Chilean firms offer high return that offsets information asymmetry costs. In addition, growth opportunities have a non-linear effect, which supports hypothesis $\mathrm{H}_{4}$ for debt issuances. Thus, when firms' bond issuers have considerable growth opportunities, stock price reactions become negative because the stock market perceives that growth opportunities are overvalued and have high information asymmetry content (Smith and Watts, 1992; Gombola et al., 1998).

Capital structure (LEV) had a positive and significant effect on stock price reactions, and therefore on shareholder wealth changes. Such an impact reveals that the stock market considers marginal debt as a control means on agency conflicts (Cai and Zhang, 2011). In addition, corporate debt has a non-linear effect on stock price reactions. This supports hypothesis $\mathrm{H}_{5}$. Therefore, when firms issue bonds, the initial positive effect on stock price reactions is reversed. This second effect is observable in firms with high leverage. For this reason, the market perceives that additional debt increases bankruptcy risk and debt agency costs. 
Table 7 shows the model (6) results for stock price reactions during equity issuances. Variables such as firm size, firm profitability, asset tangibility and issuance size had similar effects to those described in Table 6 . The asset turnover ratio showed a significant and positive effect. This suggests that higher agency costs have a negative effect on stock price because capital diffusion is attributed to higher agency conflicts. The financial deficit variable had a significant and negative effect, which indicates that capital issuances have higher information asymmetry. Finally, the stock liquidity (SLIQ) variable had a negative and significant impact on CAR. This result suggests that a higher quoted spread (lower stock liquidity) generates a negative reaction in stock prices for equity issuance (Lipson and Mortal, 2009).

Table 7. 2SLS regression model for shareholder wealth changes during equity issuance process

\begin{tabular}{|c|c|c|c|c|c|c|}
\hline \multirow{3}{*}{$\begin{array}{l}\text { Explanatory } \\
\text { variables }\end{array}$} & \multicolumn{6}{|c|}{ Dependent variable: Stock price reaction/shareholder wealth changes measured by CAR } \\
\hline & \multicolumn{5}{|c|}{ Stage at analysis window } & \multirow[b]{2}{*}{ Full process } \\
\hline & $\begin{array}{c}\text { Pre- } \\
\text { announcement }\end{array}$ & Announcement & $\begin{array}{c}\text { Post- } \\
\text { announcement }\end{array}$ & Issuance & Post-Issue & \\
\hline \multirow{2}{*}{ Constant } & 0.0107 & $0.0321 * * *$ & 0.0006 & $0.0622^{* * *}$ & $0.0712^{* * *}$ & $0.0952^{* * *}$ \\
\hline & $(0.57)$ & (3.75) & $(1.08)$ & $(2.69)$ & $(3.27)$ & (3.56) \\
\hline \multicolumn{7}{|c|}{ Ownership structure } \\
\hline \multirow{2}{*}{$\begin{array}{l}\text { Controller- } \\
\text { shareholder }\end{array}$} & $0.0127^{* * *}$ & 0.0002 & $0.0219^{* * *}$ & -0.0029 & $0.0113^{* *}$ & $0.0246^{* * *}$ \\
\hline & $(3.26)$ & $(0.58)$ & (3.69) & $(-1.60)$ & $(1.97)$ & (3.13) \\
\hline \multirow{2}{*}{$\begin{array}{l}\text { Minority- } \\
\text { shareholder }\end{array}$} & $-0.0094^{* *}$ & -0.0001 & $-0.0157^{* * *}$ & 0.0033 & 0.0048 & $-0.0135^{* * *}$ \\
\hline & $(-2.08)$ & $(-0.31)$ & $(-3.15)$ & $(1.29)$ & $(1.38)$ & $(-2.79)$ \\
\hline \multicolumn{7}{|c|}{ Leverage and growth opportunities } \\
\hline \multirow{2}{*}{ Tobin's Q } & $0.0111^{* * *}$ & -0.0010 & $0.0156^{* * *}$ & $0.0077^{* *}$ & 0.0025 & $0.0127^{* * *}$ \\
\hline & $(3.14)$ & $(-0.52)$ & $(3.69)$ & $(1.99)$ & $(0.83)$ & $(4.24)$ \\
\hline \multirow{2}{*}{$\begin{array}{l}\text { Tobin's Q } \\
\text { squared }\end{array}$} & $-0.0009^{* *}$ & -0.0003 & $-0.0012^{* * *}$ & $-0.0007^{* *}$ & -0.0003 & $-0.0012^{* * *}$ \\
\hline & $(-2.47)$ & $(-1.51)$ & $(-3.29)$ & $(-2.23)$ & $(-0.86)$ & $(-3.34)$ \\
\hline \multirow{2}{*}{ Leverage } & $-0.0212^{* * *}$ & 0.0007 & $-0.0213^{* * *}$ & $-0.0098 * *$ & -0.0029 & $-0.0197 * *$ \\
\hline & $(-3.21)$ & $(0.43)$ & $(-3.14)$ & $(-1.99)$ & $(-1.01)$ & $(-3.71)$ \\
\hline \multirow{2}{*}{$\begin{array}{l}\text { Leverage } \\
\text { squared }\end{array}$} & $0.0020^{*}$ & 0.0003 & $0.0019^{* *}$ & 0.0006 & -0.0013 & $0.0028^{* *}$ \\
\hline & $(1.95)$ & $(0.24)$ & $(2.33)$ & $(0.57)$ & $(1.12)$ & $(2.11)$ \\
\hline \multicolumn{7}{|c|}{ Other control variables } \\
\hline \multirow{2}{*}{ Agency costs } & $0.0353^{* * *}$ & 0.0002 & $0.0429^{* * *}$ & 0.0001 & 0.0017 & $0.0459^{* * *}$ \\
\hline & (3.59) & $(0.22)$ & $(4.47)$ & $(0.26)$ & $(1.36)$ & $(4.66)$ \\
\hline \multirow{2}{*}{$\begin{array}{l}\text { Financial } \\
\text { deficit }\end{array}$} & $-0.0135^{* * *}$ & -0.0029 & $-0.0184^{* * *}$ & $-0.0106^{* *}$ & 0.0013 & $-0.0198 * * *$ \\
\hline & $(-3.28)$ & $(-0.72)$ & $(-2.83)$ & $(-2.11)$ & $(0.64)$ & $(-2.91)$ \\
\hline \multirow{2}{*}{ Firm size } & 0.0008 & 0.0064 & 0.0005 & 0.0003 & 0.0009 & 0.0017 \\
\hline & $(1.05)$ & $(1.37)$ & $(0.39)$ & $(0.55)$ & $(0.81)$ & $(0.62)$ \\
\hline \multirow{2}{*}{$\begin{array}{l}\text { Firm } \\
\text { profitability }\end{array}$} & 0.0125 & 0.0019 & $0.0505^{* *}$ & 0.0102 & 0.0017 & $0.0311 * *$ \\
\hline & $(0.69)$ & $(0.31)$ & $(2.47)$ & $(0.75)$ & $(0.27)$ & $(2.55)$ \\
\hline \multirow{2}{*}{$\begin{array}{l}\text { Asset } \\
\text { tangibility }\end{array}$} & $0.0296^{* * *}$ & 0.0024 & 0.0159 & 0.0054 & 0.0081 & $0.0247^{*}$ \\
\hline & (3.48) & $(0.43)$ & $(1.18)$ & $(0.86)$ & $(1.03)$ & $(1.86)$ \\
\hline \multirow{2}{*}{ Issue size } & $-0.0127^{* *}$ & 0.0011 & $-0.0245^{* * *}$ & 0.0051 & 0.0055 & $-0.0201 * * *$ \\
\hline & $(-2.15)$ & $(0.68)$ & $(-2.74)$ & $(0.54)$ & $(0.91)$ & $(-3.02)$ \\
\hline \multirow{2}{*}{ Stock liquidity } & $-0.0496 * * *$ & -0.0098 & $-0.0291^{* * *}$ & -0.0163 & -0.0116 & $-0.0417 * * *$ \\
\hline & $(-3.21)$ & $(-0.73)$ & $(-2.77)$ & $(-1.48)$ & $(-1.09)$ & $(-3.36)$ \\
\hline
\end{tabular}




\begin{tabular}{|c|c|c|c|c|c|c|}
\hline \multirow{3}{*}{$\begin{array}{l}\text { Explanatory } \\
\text { variables }\end{array}$} & \multicolumn{6}{|c|}{ Dependent variable: Stock price reaction/shareholder wealth changes measured by CAR } \\
\hline & \multicolumn{5}{|c|}{ Stage at analysis window } & \multirow[b]{2}{*}{ Full process } \\
\hline & $\begin{array}{c}\text { Pre- } \\
\text { announcement }\end{array}$ & Announcement & $\begin{array}{c}\text { Post- } \\
\text { announcement }\end{array}$ & Issuance & Post-Issue & \\
\hline $\begin{array}{l}\text { Adjusted } \\
\text { R-squared }\end{array}$ & 0.49 & 0.33 & 0.47 & 0.37 & 0.35 & 0.51 \\
\hline Global F-test & $(55.26)^{* * *}$ & $(48.94)^{* * *}$ & $(60.13)^{* * *}$ & $(49.15)^{* * *}$ & $(40.24)^{* * *}$ & $(56.37)^{* * *}$ \\
\hline White test & $(29.47)^{* * *}$ & $(32.58)^{* * *}$ & $(27.04)^{* * *}$ & $(35.29)^{* * *}$ & $(30.18)^{* * *}$ & $(28.16)^{* * *}$ \\
\hline Hausman test & $(23.90)^{* * *}$ & $(29.02)^{* * *}$ & $(27.46)^{* * *}$ & $(33.07)^{* * *}$ & $(29.62)^{* * *}$ & $(25.08)^{* * *}$ \\
\hline Sargan test & $(39.27)$ & $(42.51)$ & $(50.73)$ & $(44.95)$ & (41.34) & $(40.04)$ \\
\hline Sector dummy & Yes & Yes & Yes & Yes & Yes & Yes \\
\hline Time dummy & Yes & Yes & Yes & Yes & Yes & Yes \\
\hline Stage dummy & No & No & No & No & No & Yes \\
\hline $\begin{array}{l}\text { Robust } \\
\text { variance }\end{array}$ & Yes & Yes & Yes & Yes & Yes & Yes \\
\hline Observations & 172 & 172 & 172 & 172 & 172 & 860 \\
\hline
\end{tabular}

Superscripts $* * *, * *,{ }^{*}$ indicate statistical significance at 1,5 , and 10 percent, respectively.

Source: Own elaboration.

Ownership structure effects were statistically significant. Controlling shareholder ownership (P1) had a positive effect on stock price reactions when firms issue equity, while minority shareholder ownership ( $\mathrm{P}_{5}$ ) had a negative effect. These results support hypotheses $\mathrm{H}_{2} \mathrm{a}$ and $\mathrm{H}_{2} \mathrm{~b}$ respectively. The positive effect of controlling-shareholder ownership suggests that the market associates equity issuance with an increasing probability that current controllers will acquire the stocks issued. This implies improved corporate performance and decreased risk (Armitage, 2002; Barnes and Walker, 2006). In addition, the negative effect of minority shareholder ownership is a reflection of wealth expropriation opportunities (Liu et al., 2016).

Growth opportunities had a positive and non-linear effect on stock price reactions, which supports hypothesis $\mathrm{H}_{4}$. As in bond issuances, growth opportunities had an effect that offset information asymmetry costs. However, greater growth opportunities contain a higher degree of information asymmetry, which can lead to the overvaluation of a firm.

Finally, corporate debt also had significant effects on stock price reactions. The negative impact of this variable indicates that equity issuances have greater information asymmetry than other financing sources. However, debt's non-linear effect suggests that when the firm's financial leverage is high, equity issuances have a positive impact on stock price reactions because additional equity mitigates bankruptcy risks and debt agency costs. This corroborates hypothesis $\mathrm{H}_{5}$.

\section{Conclusions and discussion}

The analysis of capital structure in Latin American (and particularly Chilean) firms has become more relevant in recent years. Capital structure changes, whether due to debt or equity issuances, can lead to significant changes in stock prices, and therefore redistribute shareholder wealth. An extensive literature review reveals that when firms issue debt or equity, stock prices experience positive abnormal returns mainly during the pre-announcement and post-announcement periods. This stock price reaction is sufficient to compensate for the negative abnormal returns that occur during the announcement and issuance periods. 
In Chile, few studies have been conducted in this field, and those that have been conducted generally endorse the results described by international evidence. This paper contributes to empirical evidence for emerging markets, and especially for the Chilean market, in two respects. First, we conclude that capital structure changes generate a significant stock price reaction. Our research indicates that debt issuances generated $2.43 \%$ abnormal returns and equity issuances generated $0.92 \%$. In contrast to previous studies, which have tended to state that this reaction is generated during the pre-announcement period, our results show that this positive stock price reaction is more significant during the period preceding issuance. According to regulations established by the FMC, our results also show that the information transmitted by firms prior to capital structure changes does not generate significant changes in stock price. Only debt issuances generated a $0.89 \%$ abnormal return during the pre-announcement period. This indicates that debt issuances are a signaling means for the stock market. This first result is relevant for firms, investors and policymakers. For firms this result implies that capital structure changes can generate shareholder wealth changes, while for investors this result may contribute to the improvement of investment decision-making. For policymakers this result provides them with a guide to design financial policies aimed atimproving the securities issuance processes.

Some studies have indicated that stock price reactions depend on firms' specific characteristics, but there is little clear consensus on this point. As a secondary contribution of this article, our results show that stock price reactions are affected by firms' ownership structure, growth opportunities and leverage. Controlling-shareholder ownership negatively affects stock price reactions when debt is issued, but positively affects them when equity is issued. These results indicate that, for companies with concentrated ownership, the market perceives debt issuances as a substitute means of control in relation to controllers' monitoring role. The positive reaction observed during equity issuances shows that the market associates ownership concentration by controlling shareholders with greater control and corporate performance. On the other hand, minority-shareholder ownership had a negative and significant effect on stock price reactions. This impact was only observed during equity issuances. This indicates that equity dilution is associated with greater agency conflicts between non-controlling and controlling shareholders. Therefore, this last result also illustrates that equity issuances are a means of wealth expropriation because a reduction in minority-shareholder ownership had a positive effect on market reaction. These results are relevant for firms because they reveal that the market interprets their ownership structure in a differentiated way. In addition, this is particularly relevant for Chile due its weak legal protections for investors' rights.

Growth opportunities also had significant effects on stock price reactions during issuance processes. Future growth opportunities of issuing firms had a positive and non-linear effect on shareholder wealth changes. According to Myers and Majluf (1984), this reaction implies that growth opportunities are positively valued by markets and offset information asymmetry costs. Nonetheless, the non-linear relationship (inverted-U) suggests that, when firms have greater growth opportunities, the market associates capital structure changes with the overvaluation of these opportunities, and therefore with higher information asymmetry in issued securities.

The effects of debt on shareholder wealth changes vary according to the kind of issuance. Debt had a positive effect on stock price reactions when firms issued corporate bonds, while it had a negative effect when firms issued equity. Our results show that the market assesses the financial risks of issuances. Thus, the market interprets marginal debt as a means of external control capable of increasing firm performance and mitigating agency costs. In any case, the non-linear effects of debt 
show that when debt is high, previous impacts are reversed. For the market, additional debt increases the firm's risk, while equity issuances would constitute a control that reduces this risk. These results are relevant for investors because they may help to guide their investment decisions. The findings may also be of use to firms, helping them to infer the market reaction to securities issuance processes according to their specific characteristics, such as growth opportunities and leverage.

Future studies should analyze the effects of the adoption of the OECD corporate governance practices on stock price reaction, and their role in controlling wealth expropriation. 


\section{References}

Ambarish, R., John, K. \& Williams, L. (1987). Efficient Signaling with Dividends and Investments. The Journal of Finance, 42(2), 321-344. https://doi.org/10.1111/j.1540-6261.1987.tb02570.x

Ang, J., Cole, R. \& Lin, J. (2000). Agency costs and ownership structure. The Journal of Finance, 55(1), 81-106. https://doi.org/10.1111/0022-1082.00201

Armitage, S. (2002). Do Underwriters Certify Value? Evidence from UK Rights Issues and Open Offers. Journal of Business Finance \& Accounting, 29(9-10), 1239-1273. https://doi.org/10.1111/1468-5957.00468

Armitage, S. (2010). Block Buying and Choice of Issue Method in UK Seasoned Equity Offers. Journal of Business Finance \& Accounting, 37(3-4), 422-447. https://doi.org/10.1111/j.1468-5957.2010.02188.x

Asquith, P. \& Mullins, D. (1986). Equity issues and offering dilution. Journal of Financial Economics, 15(1-2), 6189. https://doi.org/10.1016/0304-405X(86)90050-4

Baker, M. \& Wurgler, J. (2002). Market timing and capital structure. The Journal of Finance, 57(1), 1-32. https:// doi.org/10.1111/1540-6261.00414

Barnes, E. \& Walker, M. (2006). The Seasoned-Equity Issues of UK Firms: Market Reaction and Issuance Method Choice. Journal of Business Finance \& Accounting, 33(1-2), 45-78. https://doi.org/10.1111/ j.1468-5957.2006.01354.x

Bayless, S. \& Chaplinsky, M. (1996). Is there a window of opportunity for seasoned equity issuance? The Journal of Finance, 51(1), 253-278. https://doi.org/10.1111/j.1540-6261.1996.tb05209.x

Brown, S. \& Warner, J. (1985). Using Daily Stock Returns: The Case of Event Studies. Journal of Financial Economics, 14(1), 3-31. https://doi.org/10.1016/0304-405X(85)90042-X

Burton, B., Lonie, A. \& Power, D. (2000). The impact of corporate growth opportunities on the market response to new equity announcement. Applied Financial Economics, 10(1), 27-36. https://doi. org/10.1080/096031000331897

Cai, I. \& Zhang, Z. (2011). Leverage Change, Debt Overhang and Stock Prices. Journal of Corporate Finance, 17(3), 391-402. https://doi.org/10.1016/j.jcorpfin.2010.12.003

Castillo, A. (2004). The announcement effect of bond and equity issues: evidence from Chile. Estudios de Economía, 31(2), 177-205.

Céspedes, I., González, M. \& Molina, C. (2010). Ownership and capital structure in Latin America. Journal of Business Research, 63(3), 248-254. https://doi.org/10.1016/j.jbusres.2009.03.010

Chen, P. \& Shehu, E. (2009). Stock Price Reaction to Announcements of Capital Structure Changes-from an Industry Leverage Ratio Perspective. Sweden: Lund University.

Chong, A. \& López de Silanes, F. (2007). Corporate governance in Latin America. Inter-America Development Bank. Working Paper N. ${ }^{\circ}$ 591. https://doi.org/10.2139/ssrn.1820067

Chung, K., Wright, P. \& Charoenwong, C. (1998). Investment opportunities and market reaction to capital expenditure decision. Journal of Banking \& Finance, 22(1), 41-60. https://doi.org/10.1016/S03784266(97)00021-6

Cooney, I. \& Kalay, A. (1993). Positive Information from Equity Issue Announcement. Journal of Financial Economics, 33(2), 149-172. https://doi.org/10.1016/0304-405X(93)90002-S

Corrado, C. (1989). A Nonparametric Test for Abnormal Security-Price Performance in Event Studies. Journal of Financial Economics, 23(2), 385-395. https://doi.org/10.1016/0304-405X(89)90064-0

Corrado, C. \& Zivney, T. (1992). The Specification and Power of the Sign Test in Event Study Hypothesis Tests Using Daily Stock Returns. Journal of Financial and Quantitative Analysis, 27(3), 465-478. https://doi. org/10.2307/2331331

De Medeiros, O. \& Matsumoto, A. (2005). Brazilian market reaction to equity issue announcements. Revista de Administração Contemporânea, 9(2), 36-46. https://doi.org/10.1590/S1415-65552005000600004

Demsetz, H. \& Lehn, K. (1985). The structure of corporate ownership: Causes and consequences. Journal of Political Economy, 93(6), 1155-1177. https://doi.org/10.1086/261354 
Denis, D. (1994). Investment opportunities and the market reaction to equity offerings. Journal of Financial and Quantitative Analysis, 29(2), 159-177. https://doi.org/10.2307/2331220

Dierkens, N. (1991). Information asymmetry and equity issues. Journal of Financial and Quantitative Analysis, 26(2), 181-199. https://doi.org/10.2307/2331264

Eckbo, B. \& Masulis, R. (1992). Adverse selection and the rights offer paradox. Journal of Financial Economics, 32(3), 293-322. https://doi.org/10.1016/0304-405X(92)90030-2

Fleming, G., Heaney, R. \& McCosker, R. (2005). Agency costs and ownership structure in Australia. PacificBasin Finance Journal, 13(1), 29-52. https://doi.org/10.1016/j.pacfin.2004.04.001

Gombola M., Lee, H. \& Liu, F. (1998). Further Evidence on Insider Selling Prior to Seasoned Equity Offering Announcements: The Role of Growth Opportunities. Journal of Business, Finance and Accounting, 26(5-6), 621-649. https://doi.org/10.1111/1468-5957.00269

Harris, M., \& Raviv, A. (1990). Capital structure and the informational role of debt. The Journal of Finance, 45(2), 321-349. https://doi.org/10.1111/j.1540-6261.1990.tb03693.x

Healy, P. \& Palepu, K. (1990). Earnings and Risk Changes Surrounding Primary Stock Offers. Journal of Accounting Research, 28(1), pp. 25-48. https://doi.org/10.2307/2491216

Jensen, M. (1986). Agency costs of free cash flow, corporate finance, and takeovers. The American Economic Review, 76(2), 323-329.

Jensen, M. \& Meckling, W. (1976). Theory of the firm: Managerial behavior, agency costs and ownership structure. Journal of Financial Economics, 3(4), 305-360. https://doi.org/10.1016/0304-405X(76)90026-X

Jensen, M., Crutchley, C. \& Hudson, C. (1994). Market reaction to equity offer reasons: What information do managers reveal? Journal of Economics \& Finance, 18(3), 313-329. https://doi.org/10.1007/ BF02920490

Leal, R., \& Amaral, A. (2000). Um momento para o insider trading: o período anterior ao anúncio de uma emissão pública de ações. In Leal, R., Costa Ir. N., Lemgruber, E.F. (org). Finanças Corporativas (pp. 158-173). Coleção Coppead de Administração.

Leland, H. \& Pyle, D. (1977). Informational asymmetries, financial structure, and financial intermediation. The Journal of Finance, 32(2), 371-387. https://doi.org/10.2307/2326770

Lipson, M. \& Mortal, S. (2009). Liquidity and capital structure. Journal of Financial Markets, 12(4), 611-644. https://doi.org/10.1016/j.finmar.2009.04.002

Liu, I., Akbar, S., Ali Shah, S., Zhang, D. \& Pang, D. (2016). Market reaction to seasoned offerings in China. lournal of Business Finance \& Accounting, 43(5-6), 597-653. https://doi.org/10.1111/jbfa.12198

Lucas, D. \& McDonald, R. (1990). Equity issues and stock price dynamics. The Journal of Finance, 45(4), 10191043. https://doi.org/10.1111/j.1540-6261.1990.tb02425.x

MacKinlay, A. (1997). Event Studies in Economics and Finance. Journal of Economic Literature, 35(1), 13-39.

Masulis, R. (1980). The effects of capital structure change on security prices: A study of exchange offers. Journal of Financial Economics, 8(2), pp. 139-178. https://doi.org/10.1016/0304-405X(80)90015-X

Masulis, R. \& Korwar, A. (1986). Seasoned equity offerings: An empirical investigation. Journal of Financial Economics, 15(1-2), 91-118. https://doi.org/10.1016/0304-405X(86)90051-6

McLaughlin, R., Safieddine, A. \& Vasudevan, G. (1998). The information content of corporate offerings of seasoned securities: an empirical analysis. Financial Management, 27(2), 31-45.

Mikkelson, W. \& Partch, M. (1986). Valuation effects of security offerings and the issuance process. Journal of Financial Economics, 15(1-2), 31-60. https://doi.org/10.1016/0304-405X(86)90049-8

Mitto, U. (1996). The Bad News Bearers. Canadian Investment Review, 7(4), 23-27.

Modigliani, F. \& Miller, M. (1958). The cost of capital, corporate finance, and theory of investment. American Economic Review, 48(3), 655-669.

Modigliani, F. \& Miller, M. (1963). Corporate income taxes and the cost of capital: A correction. American Economic Review, 53(3), 433-443. 
Myers, S. (1977). Determinants of corporate borrowing. Journal of Financial Economics, 5(2), 147-175. https:// doi.org/10.1016/0304-405X(77)90015-0

Myers, S. \& Majluf, N. (1984). Corporate financing and investment decisions when firms have information the investors do not have. Journal of Financial Economics, 13(2), 187-221. https://doi.org/10.1016/0304405X(84)90023-0

Pilotte, E. (1992). Growth Opportunities and the Stock Price Response to New Financing. The lournal of Business, 65(3), 371-394. https://doi.org/10.1086/296576

Quyhn-Nhu, D. (2009). Leverage, Growth Opportunities and Stock Price Response to New Financing. International Journal of Business and Management, 4(9), 35-49. https://doi.org/10.5539/ijbm.v4n9p35

Rajan, R. \& Zingales, L. (1995). What do we know about capital structure: some evidence from international data. The lournal of Finance, 50(5), 1421-1460. https://doi.org/10.1111/j.1540-6261.1995.tb05184.x

Raymar, S. (1993). The Financing and Investment of a Levered Firm under Asymmetric Information. The Journal of Financial Research, 16(4), 321-336. https://doi.org/10.1111/j.1475-6803.1993.tb00151.x

Ross, S. (1977). The Determination of Financial Structure: The Incentive-Signalling Approach. The Bell Journal of Economics, 8(1), 23-40. https://doi.org/10.2307/3003485

Saens, R. (1999). Premia in Emerging Market ADR Prices: Evidence from Chile. Abante, 2(1), 51-70.

Smith, C., \& Watts, R. (1992). The Investment Opportunities Set and Corporate Financing, Dividend and Compensation Policies. Journal of Financial Economics, 32(3), 263-292. https://doi.org/10.1016/0304405X(92)90029-W

Vithessonthi, C. (2008a). The Short-Run Performance of Initial Public Offerings: An Empirical Study for Thailand. The Business Review, 9(2), 48-54.

Vithessonthi, C. (2008b). What Explains Stock Market Reactions to Proposals to Increase the Authorized Common Stock? Journal of International Finance and Economics, 8(1), 126-136.

Vithessonthi, C. (2008c). Stock Price Performance of Initial Public Offerings: The Thai Experience. Journal of International Finance and Economics, 8(2), 30-43.

Welch, I. (2004). Capital Structure and Stock Returns. Journal of Political Economy, 112(1), 106-131. https:// doi.org/10.1086/379933 